\title{
Online Teaching Design for Innovation and Invention Courses
}

\author{
Jiang Fan \\ School of Mechanical and Electrical Engineering, \\ Guangzhou University \\ Guangzhou, China \\ Jiangfan2008@gzhu.edu.cn
}

\author{
Xiao Zhongmin, Wu Qingfeng, Liu Zhenzhang \\ School of Mechanical and Electrical Engineering, \\ Guangzhou University \\ Guangzhou, China
}

\begin{abstract}
Innovation and invention courses play a crucial role in improving students' innovative ability. Through online mode, more students can learn innovative methods and thus improve their innovative ability. Therefore, it is imperative to construct online courses. This paper integrates TRIZ theory and Extenics innovation method, aiming to construct IASE innovation method set based on solving process, design teaching content, teaching resources, teaching activities and teaching evaluation, and discuss the idea of developing practical case resources so as to provide references for online teaching design for innovation and invention courses.
\end{abstract}

Keywords-Online course; Innovation and invention; Teaching design; Innovative design case; Researched teaching

\section{INTRODUCTION}

Innovation and invention course belongs to innovation method course. It is of great value to teach students how to solve innovative problems and improve students' innovative ability [1-2]. This course is based on IASE (Identification, Analysis, Solving, Evaluation), which integrates TRIZ theory and Extenics Innovation Method. It teaches various innovative tools according to the process of Problem Solution, and helps students grasp innovative methods quickly through case assistance, carry out innovative practice according to the examples, and enhance their innovative ability [4]. With the rise of online courses, it has brought a strong impact on multimedia teaching. This new form of online multimedia teaching will bring about changes in teaching, and trigger many teachers to research and apply online courses. However, there are few literatures on online courses of innovative courses. Only some teachers discuss course teaching methods of innovative courses. Jiang, et al have studied the project-based teaching of TRIZ theory and innovation method course, using the concept design of daily chemicals as a training project, through which students can improve the application ability of innovation method [3]. Wang reformed the teaching of creative thinking and innovative methods, trained students' innovative interest by using interesting tests, and so on. Considering the learning characteristics of students at different stages, Zhang, et al constructed an innovative method curriculum system for students at all levels to meet the needs of the construction and development of innovative method curriculum [5]. Tu adopts the mixed teaching method, integrates the teaching contents of innovative methods, reforms the assessment methods, and improves students' enthusiasm for innovation and practice [6]. Lei reformed the teaching process of entrepreneurship foundation, and improved the teaching effect by combining online and offline teaching, strengthening practical guidance and reversing teaching [7]. These studies provide a reference for improving the curriculum construction of innovative methods, but in online courses, the lack of face-to-face communication between teachers and students makes teaching design particularly important. Liu has made a thorough exploration of the teaching design mode of micro-courses under MOOC environment [8]. He has studied the teaching design mode of MOOC environment [9]. These researches play an important role in teaching design under MOOC environment, but it needs be further studied for specific courses.

\section{TEACHING DESIGN OF INNOVATION AND INVENTION COURSE}

At present, there are many innovative methods, but the study hours in the university are limited, so it is necessary to integrate the teaching content. This course integrates TRIZ theory and extension innovation method [10-19], and constructs IASE innovation method set based on solving process.

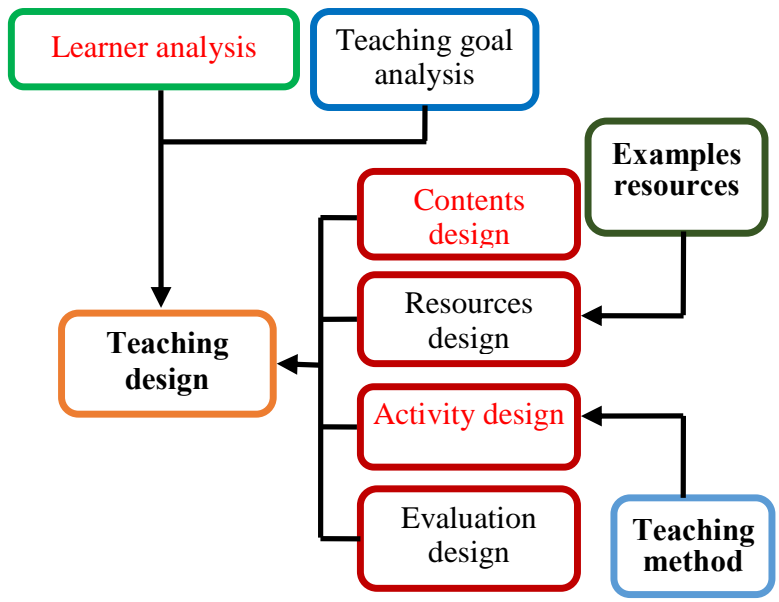

Fig. 1 Innovation and invention teaching design 
Innovation and invention teaching design is based on the analysis of learners and teaching objectives. It designs teaching content and resources, including teaching content design, teaching resources design, teaching activities design and teaching evaluation design, as shown in Fig. 1.

According to learner analysis, students in local universities have relatively weak self-control ability, strong utilitarianism, and like to learn knowledge in practice. Therefore, a large number of knowledge application cases need to be set up in the curriculum.

For teaching objectives, this course requires students to master the basic innovative methods of IASE methodology set, have the application ability of basic innovative tools, and corresponding innovative problem-solving ability, and have the quality of innovative thinking.

The design of teaching content is mainly based on IASE innovation method. According to the process of project CDIO (conceive, design, implement, operation) and problem-solving process, the knowledge points of innovation method are organized. As shown in Table 1, the knowledge points are combined with examples to facilitate students' understanding.

TABLE I CONTENTS OF IASE INNOVATION METHOD

\begin{tabular}{|c|c|c|}
\hline $\begin{array}{l}\text { Solving } \\
\text { steps }\end{array}$ & $\begin{array}{l}\text { Project } \\
\text { execution } \\
\text { steps }\end{array}$ & Knowledge \\
\hline Identification & Conceive & $\begin{array}{l}\text { Extenics modeling, } \\
\text { Functional analysis, Causal } \\
\text { analysis, Substance field } \\
\text { analysis, Contradiction } \\
\text { analysis and standard } \\
\text { parameters. }\end{array}$ \\
\hline Analysis & Design & $\begin{array}{lr}\text { Extended methods, How to } \\
\text { model and scientific } \\
\text { effects, } \\
\text { method, } & \text { STC operati-screen } \\
\text { method, } & \text { Final ideal } \\
\text { solution, } & \text { Resource } \\
\text { analysis. } & \end{array}$ \\
\hline Solving & Implement & 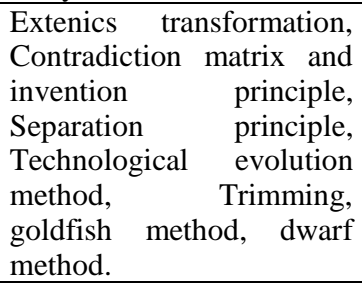 \\
\hline Evaluation & Operate & $\begin{array}{l}\text { Ideality, Main parameter } \\
\text { value (MPV), The priority- } \\
\text { degree evaluation method. }\end{array}$ \\
\hline
\end{tabular}

Learning resources design includes teaching videos, courseware and learning expansion documents. In addition to course application background, animation, teaching plan, exercises and so on, learning extended documents mainly enrich examples of innovative design of daily necessities, strengthen innovative thinking training given design requirements, and provide a large number of innovative design examples for students to refer to independently.
The design of teaching activities should make students' individual autonomous learning, interaction between teachers and students, and offline activities under control. The average retention rate of learning content is relatively high among students' discussion, practice and teaching others. Therefore, online teaching activities include online communication, homework submission, online testing, etc. By setting up discussion areas, students can learn more effectively. Now teachers and students interact, students discuss the understanding and application of knowledge points in the discussion area, so as to improve the learning effect.

The design of teaching evaluation includes formation evaluation and summary evaluation. This course adopts the combination of online footprint automatic evaluation (including video viewing, document reading, leaving a message in the discussion zone, etc.) and final report to evaluate the course. The proportion of each part is: $30 \%$ of online learning, $10 \%$ of meeting class, $40 \%$ of homework report and $20 \%$ of forum discussion.

\section{TEACHING METHOD DESIGN OF INNOVATION AND INVENTION}

$\mathrm{T}$ The online teaching process is organized according to the research-based teaching mode and CDIO educational concept, and PTES teaching method is established, which includes problem introduction, teaching (including case description), exercise and knowledge summary, is seen in Table 2.

TABLE II PTES TEACHING IMPLEMENTATION STEPS

\begin{tabular}{|c|c|c|c|}
\hline $\begin{array}{l}\text { Teachin } \\
\text { g steps }\end{array}$ & Teaching contents & $\begin{array}{c}\text { Knowledge } \\
\text { learning effect } \\
\text { to be achieved }\end{array}$ & $\begin{array}{l}\text { The ability to } \\
\text { achieve the } \\
\text { training effect }\end{array}$ \\
\hline $\begin{array}{l}\text { Problem } \\
\text { introduct } \\
\quad \text { ion }\end{array}$ & $\begin{array}{c}\text { For knowledge } \\
\text { points, ask } \\
\text { questions to enable } \\
\text { students to } \\
\text { conceive and draw } \\
\text { knowledge that } \\
\text { needs to be taught. }\end{array}$ & $\begin{array}{l}\text { Think about } \\
\text { why and what } \\
\text { is the point of } \\
\text { knowledge. }\end{array}$ & $\begin{array}{c}\text { Problem } \\
\text { conceiving } \\
\text { ability. }\end{array}$ \\
\hline Teaching & $\begin{array}{l}\text { Knowledge points, } \\
\text { application } \\
\text { methods and } \\
\text { related cases. }\end{array}$ & $\begin{array}{l}\text { Understand } \\
\text { knowledge and } \\
\text { grasp the way } \\
\text { of application. }\end{array}$ & $\begin{array}{l}\text { Knowledge } \\
\text { understanding } \\
\text { and knowledge } \\
\text { reasoning。 }\end{array}$ \\
\hline Exercise & $\begin{array}{c}\text { Students } \\
\text { understand } \\
\text { knowledge points } \\
\text { and their } \\
\text { applications } \\
\text { through lots of } \\
\text { exercises. }\end{array}$ & $\begin{array}{l}\text { Understand } \\
\text { knowledge } \\
\text { from different } \\
\text { angles and } \\
\text { master } \\
\text { knowledge in } \\
\text { practice. }\end{array}$ & $\begin{array}{l}\text { Knowledge } \\
\text { application } \\
\text { ability, } \\
\text { practical } \\
\text { ability and } \\
\text { teamwork } \\
\text { ability. } \\
\end{array}$ \\
\hline $\begin{array}{c}\text { Summar } \\
\mathrm{y}\end{array}$ & $\begin{array}{c}\text { Summary of } \\
\text { knowledge, } \\
\text { combined with } \\
\text { daily reality, gives } \\
\text { practical } \\
\text { application cases. }\end{array}$ & $\begin{array}{l}\text { Knowledge } \\
\text { self- } \\
\text { construction, } \\
\text { knowledge } \\
\text { aggregation } \\
\text { and } \\
\text { reinforcement. }\end{array}$ & $\begin{array}{c}\text { Knowledge } \\
\text { discovery } \\
\text { ability. }\end{array}$ \\
\hline
\end{tabular}




\section{CONSTRUCTION OF INNOVATION AND INVENTION CASE RESOURCES}

For case resources construction, this course is divided into two aspects: knowledge point cases and comprehensive cases.

1) For knowledge point cases, 2-3 related cases are given in each knowledge point catalogue, such as explaining the divergence tree method and giving the divergence of linear reciprocating motion: from crank-slider mechanism to gearrack mechanism, cam mechanism, incomplete gear, etc., as shown in Figure 2.

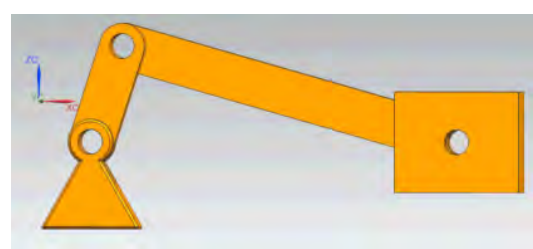

Crank slider mechanism

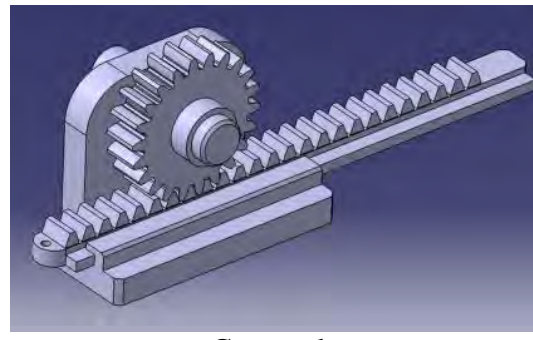

Gear rack
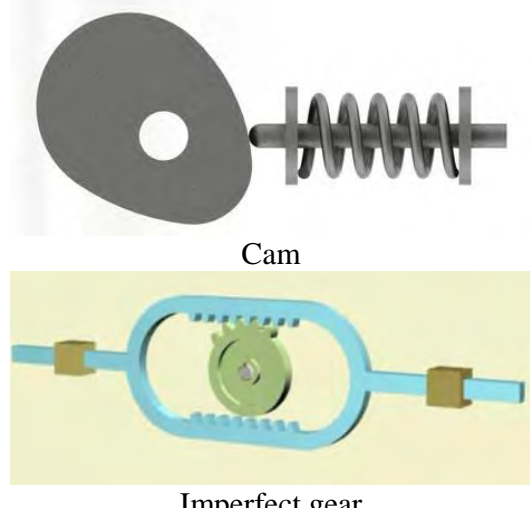

Imperfect gear

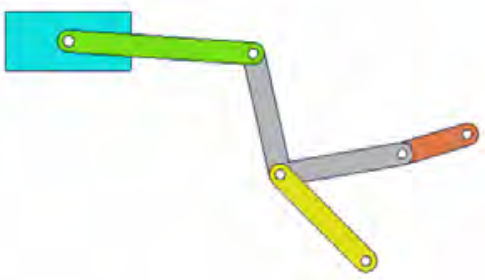

Combined mechanism

Fig. 2 Case of divergent tree of reciprocating linear motion mechanism

2) For comprehensive cases, collect some typical cases of the invention process, and give the application of various tools in the process of problem identification, problem analysis, problem solving and scheme evaluation.

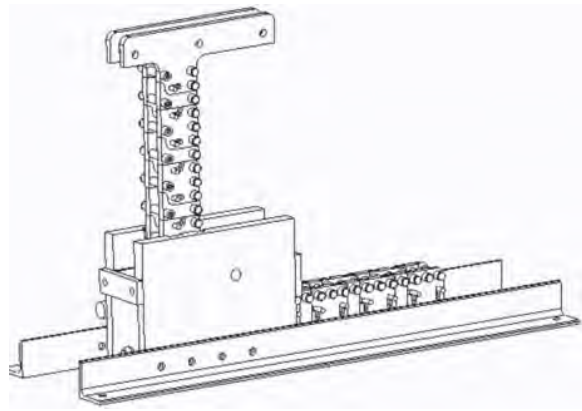

Fig. 3 Innovative design case of rigid chain

As shown in Figure 3, in the innovative design of rigid chain, firstly, we should identify the innovative problems and understand the shortcomings of existing rigid chains, then analyze these problems and establish relevant models. Then, we use the solving tools in IASE to solve them, establish innovative solutions, and finally evaluate the solutions and select the best scheme to implement.

Based on the above instructional design, the innovation and invention online course platform is shown in Figure 4.

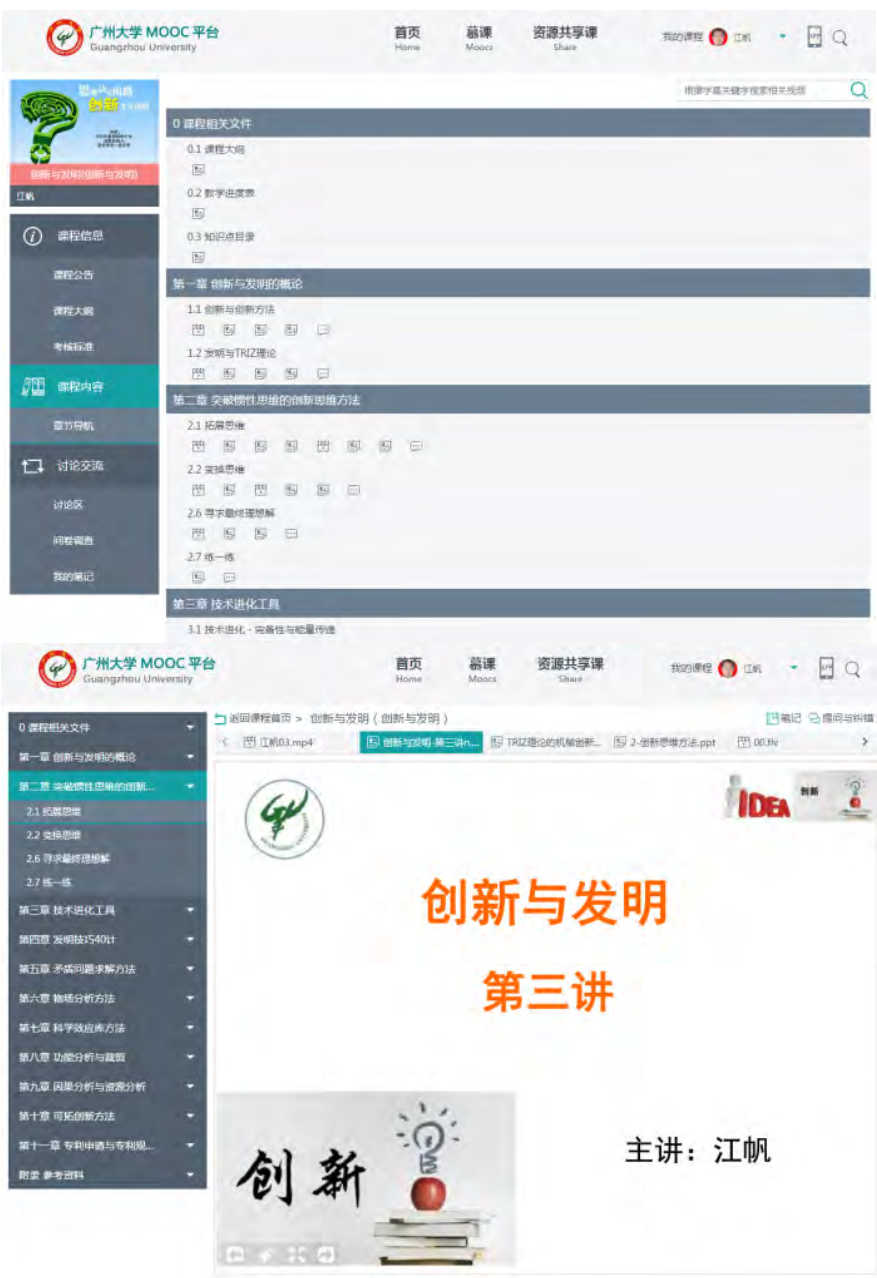

Fig. 4 Online course of innovation and invention under construction 


\section{EVALUATION OF CURRICULUM DESIGN EFFECT}

According to the general construction standard, the evaluation indexes are: curriculum orientation, ILOs design, teaching content design, teaching strategy design, teaching progress design, assessment structure and assessment standard design, as shown in Fig. 5. The weights of these indicators are $0.1,0.2,0.3,0.2,0.1$ and 0.1 respectively. The evaluation of each index needs to be quantified. The correlation function is used here, as shown in Formula (1), and then the correlation value is standardized (Formula (2). Finally, the priority-degree evaluation value of curriculum design effect is obtained according to the goodness calculation formula (3). The course is qualified if the priority-degree evaluation value is more than 0.65 , better as the value more than 0.8 and best as more than 0.9 .

$$
k_{j}\left(x_{i}\right)=\left\{\begin{array}{lc}
1, & x_{i}=\text { higher } \\
0.5, & x_{i}=\text { high } \\
0, & x_{i}=\text { medium } \\
-0.5, & x_{i}=\text { poor } \\
-1, & x_{i}=\text { verypoor }
\end{array}\right.
$$

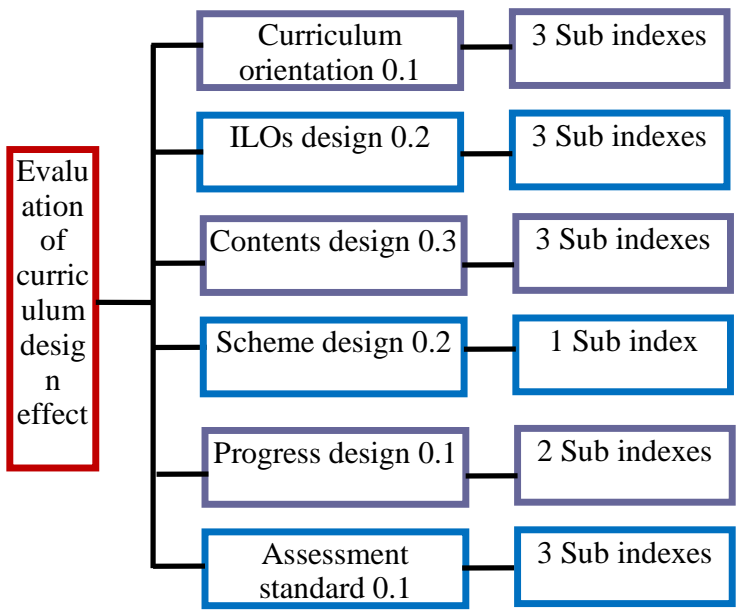

Fig. 5 Evaluation index system

$$
\begin{gathered}
k_{i j}= \begin{cases}\frac{k_{i}\left(x_{j}\right)}{\max _{x \in x_{0}} k_{i}(x)}, & k_{i}\left(x_{j}\right)>0 \\
\frac{k_{i}\left(x_{j}\right)}{\max _{x \notin x_{0}}\left|k_{i}(x)\right|}, & k_{i}\left(x_{j}\right)<0\end{cases} \\
C\left(x_{j}\right)=\left(\alpha_{1}, \alpha_{2}, \ldots, \alpha_{n}\right)\left(\begin{array}{c}
k_{1 j} \\
k_{2 j} \\
\ldots \\
k_{n j}
\end{array}\right)=\sum_{i=2}^{n} \alpha_{i} k_{i j}
\end{gathered}
$$

Where, $\alpha_{i}$ is the weights of the $i^{\text {th }}$ index, $k_{j}\left(x_{i}\right)$ is the correlation value of the $i^{\text {th }}$ index, $k_{i j}$ is standardized correlation value, $C\left(x_{j}\right)$ is the priority-degree evaluation value.

\section{CONCLUSIONS}

Innovation and invention course is a general course to expand thinking and cultivate innovation ability. Because it involves a wide range of aspects, how to stimulate students' interest in learning? How to improve students' learning efficiency needs instructional design. At the same time, online courses lack face-to-face interaction between teachers and students. How to improve the teaching effect needs instructional design more. In this paper, the teaching objectives, teaching content, teaching methods and so on are designed, the construction scheme of practical case resources, and the evaluation system of curriculum design effect are given to improve the reference for online curriculum development.

\section{ACKNOWLEDGMENT}

This work was financially supported by Guangdong Higher Education Teaching Reform Project of Higher Education (Guangdong High Education Letter [2016] No.236-412), Guangdong Graduate Education Innovation Project (Guangdong Teaching and Research Letter [2016] No. 392016JGXM_MS_50), Guangzhou teaching achievements cultivation project (Guangzhou Education [2017] 93), Guangzhou university innovation and entrepreneurship education project (201709k20), Guangdong province quality online course "innovation and invention" (Guangdong education high letter [2017]214).

\section{REFERENCES}

[1] Zhou Jun, Tong Shaocheng, Zhang Xing et al. Exploration and practice of multi-dimensional innovation and entrepreneurship education system construction mode. Computer Education, 2017, 9: 43-47.

[2] Wang Xueying, Yu Xijin. Curriculum of innovation and entrepreneurship based on OBE. Journal of Shenyang Normal University, 2017, 5: 123-127.

[3] Jiang Tao, Zhao Haoyu, Sun Yutao. Research on Project-based Teaching of TRIZ Theory and Innovative Methods. Vocational Space-time, 2012, 2: 112-113.

[4] Wang Yu. A Preliminary Study on Improving the Teaching Quality of Creative Thinking and Innovative Methods. Journal of Liaoning University of Science and Technology, 2016, 18 (2): 51-52

[5] Zhang Wai, Gao Xinrui, Feng Lin. Based on innovation and entrepreneurship training of innovative methods, curriculum system construction. Heilongjiang Education (Higher Education Research \& Appraisal), 2017, 11: 61-63.

[6] Tu Liping, Shen Zhenqian, Shi Fengdong, et al. Discussion and research on teaching problems of innovative methods courses. Laboratory Science, 2018, 21(1): 118-123.

[7] Lei Guohui. Research on the teaching reform of entrepreneurial foundation based on the cultivation of innovative and entrepreneurial talents. Journal of Jilin Radio and TV University, 2018, 17(6): 25-26.

[8] Liu Quan. Exploration and Research on the Design Model of Microteaching Based on MOOC Environment [D]. Master's Degree Thesis of Yunnan University, 2016.6

[9] He Qing. Teaching Design Model Based on MOOC Environment [J]. Journal of Hubei Correspondence University, 2016, 29 (14): 105-107

[10] Jiang Fan, Zhang Chunliang, Wu Qingfeng, et al. Study on the Innovation Competency Model of Students with Mechanical Major. Advances in Computer Science Research, 2017, 70(5): 96-100. 
[11] Jiang Fan, Zhang Chunliang, Wang Yijun, et al. Study on the Thinking Expand Method in the Mechanism Theory Teaching. The Proceeding of the 11th International Conference on Computer Science \& Education, 2016.8: 877-882

[12] Jiang Fan.TRIZ. Innovative application and innovative engineering education research[J]. Beijing Institute of Technology Press, 2013: 36.

[13] Jiang Fan Yang Penghai. Research on the fusion method of TRIZ theory and Extenics. Journal of Guangzhou University(Natural Science Edition), 2014,13(6): 59-64.

[14] Jiang Fan. Comparison between TRIZ and Extenics and research on fusion mechanism. Beijing Institute of Technology Press, 2015:87.

[15] Jiang Fan, Zhang Chunliang, Wang Yijun. Construction of initiative practice ability cultivation system for mechanical major students. Research in Higher Education of Engineering, 2016(1): 187-192.

[16] Jiang Fan, Ling Chengxiang. Design of injector used in the marine desalination equipment based on Extenics. Technology of Water Treatment, 2015, 41(12): 122-125.

[17] Jiang Fan, Fang Weizhong, Yue Pengfei, et al. Mechanical kinematic scheme design of packing lifting device based on ideal superiority evaluation method. Packaging Engineering, 2016, 37(14): 11-15.

[18] Jiang Fan, Wang Yijun, Xiao Zhongmin, et al. Application of Extenics in the practical course of mechanical major. Experiment Science and Technology, 2013, 11(6): 20-23.

[19] Jiang Fan, Chen Jiangdong, Xiao Zhongmin, et al. Study on the innovation and entrepreneurship curriculum system for graduates based on Extenics. Advances in Social Science, Education and Humanities Research, 2018, 176(6): 110-114. 